\title{
PERENCANAAN OBAT PASIEN BPJS RAWAT JALAN DENGAN METODE KONSUMSI DI INSTALASI FARMASI RSUD KABUPATEN BANDUNG
}

\section{Kamelia Agustini, Akhmad Priyadi dan Nurul Fauziah}

Akademi Farmasi Bumi Siliwangi Bandung Jawa Barat, Indonesia

Email: kamelalmira@gmail.com, akhmadpriyadi@yahoo.com dan nurfa91.nf@gmail.com

\section{Abstract}

The purpose of this study was to determine the suitability of the process of drug availability planning with the method of consumption and factors that affect the discrepancy of the drug plan for the patient BPJS Outpatient Health in Pharmacy Installation one of the Regional General Hospital in Bandung district. This method of research is a descriptive research with retrospective retrieval data to report the amount of usage and the remaining drug BPJS in Pharmacy Installation one of the Regional General Hospital in Bandung District. By using the consumption method, the results showed that from 88 drug samples, the result of the matching of drug procurement in October, November and December 2017 were 56.82\%, 54,55\% and $80,68 \%$ respectively. Factors that affect the mismatch of planning include: pending, empty distributors, not impressive and the product is not in the e-catalog list.

Keywords: Drug Planning, Methods of Consumption, Pharmaceutical Installation.

\begin{abstract}
Abstrak
Tujuan penelitian ini untuk mengetahui kesesuaian proses perencanaan ketersediaan obat dengan metode konsumsi dan faktor yang mempengaruhi ketidaksesuaian perencanaan obat tersebut untuk pasien BPJS Kesehatan rawat jalan di Instalasi Farmasi salah satu Rumah Sakit Umum Daerah di Kabupaten Bandung. Metode Penelitian ini merupakan penelitian deskriptif dengan pengambilan data secara retrospektif terhadap laporan jumlah pemakaian dan sisa obat BPJS di Instalasi Farmasi salah satu Rumah Sakit Umum Daerah di Kabupaten Bandung. Dengan menggunakan metode konsumsi, hasil penelitian menunjukkan bahwa dari 88 sampel obat, didapatkan hasil kesesuaian pengadaan obat pada bulan Oktober, November dan Desember 2017 berturut-turut adalah $56,82 \%$, 54,55\% dan 80,68\%. Faktor yang mempengaruhi ketidaksesuaian perencanaan diantaranya: pending, kosong distributor, belum terpesankan dan produk sudah tidak masuk daftar $e$-catalog.
\end{abstract}

Kata kunci: Instalasi Farmasi, Metode Konsumsi, Perencanaan Obat.

\section{Pendahuluan}

Peraturan Menteri Kesehatan Republik Indonesia nomor 56 tahun 2014 tentang Klasifikasi dan Perizinan Rumah Sakit, menyebutkan bahwa rumah sakit yaitu institusi 
pelayanan kesehatan, menyelenggarakan pelayanan kesehatan perorangan secara paripurna, menyediakan pelayanan rawat inap, rawat jalan, dan juga gawat darurat (Kementerian Kesehatan Republik Indonesia, 2014) .

Perbaikan sistem mutu dan keselamatan penggunaan obat yang berkelanjutan dapat membantu rumah sakit dalam menyusun kebijakan berkaitan dengan manajemen penggunaan obat yang efektif, yang dilakukan oleh Instalasi Farmasi (Kementerian Kesehatan Republik Indonesia, 2016).

Hasil penelitian dengan metode konsumsi menunjukkan bahwa 166 item pengadaan dan 48 item tidak diadakan. Buffer stock yang digunakan sebesar $30 \%$, sedangkan lead time selama 7 hari. Pemakaian rata-rata terbesar adalah RL sebanyak 16.321 plabot. Perbandingan dengan perencanaan RSUD Tidar Kota Magelang 61\% sesuai dengan perencanaan, dan 39\% tidak sesuai dengan perencanaan penelitian. Analisa konsumsi dapat digunakan sebagai Penetapan kebutuhan obat yang dilakukan dengan mempertimbangkan beberapa aspek dalam perencanaan obat di rumah sakit yaitu pemakaian periode sebelumnya, anggaran, standarisasi obat atau formularium, kapasitas gudang dan stok akhir, lead time dan stok pengaman, jumlah kunjungan dan pola penyakit serta standar terapi (Murtafi, Yuliastuti, \& Hidayat, 2014).

Salah satu Rumah Sakit "X" memiliki visi yaitu menjadi Rumah Sakit Umum Daerah terdepan dan rujukan utama di Jawa Barat tahun 2018, sejak 1 Januari 2014 telah melaksanakan pelayanan untuk pasien BPJS (Badan Penyelenggara Jaminan Sosial), yang merupakan pemindahan dari pasien Askes (Asuransi Kesehatan).

Sejak dibuka pelayanan BPJS di RSUD tersebut, penerimaan pasien mengalami peningkatan dalam kurun waktu 2014 sampai 2015, data menunjukkan peningkatan sampai $57 \%$ di rawat jalan dan $63 \%$ di rawat inap (data laporan tahunan di salah satu RSUD di Kabupaten Bandung pada tahun 2014-2015). Karena semakin banyaknya pasien BPJS, maka penggunaan obat mengalami peningkatan. (Mendrofa \& Suryawati, 2016)

Pelaksanaan yang tidak baik dalam metode pencatatan, penyimpanan dan perencanaan serta pelaporan terhadap pengelolaan persediaan obat rumah sakit dapat mempengaruhi efektifitas kegiatan pengelolaan persediaan obat Rumah sakit (Febreani \& Chalidyanto, 2016).

Pengendalian persediaan sangat perlu untuk diperhatikan, karena ada kaitan langsung dengan biaya yang ditanggung suatu perusahaan akibat adanya persediaan, yang seharusnya dapat seimbang dengan kebutuhan. Persediaan tinggi mengakibatkan perusahaan harus menanggung resiko kerusakan dan biaya penyimpanan yang cukup tinggi dan biaya investasi yang besar (Ristono, 2018). Data menunjukkan rata-rata kunjungan pasien BPJS untuk rawat jalan ke Rumah Sakit mencapai 1.331 pasien per hari, menyebabkan jumlah resep yang diterima pun mencapai angka seribu. Hal ini mengakibatkan perlunya stok yang memadai agar resep yang ditulis oleh dokter, dapat terpenuhi. Karena, jika tidak terpenuhi akan menyebabkan kerugian bagi Rumah Sakit. Berdasarkan UU RI Nomor 24 tahun 2011 tentang Badan Penyelenggara Jaminan Sosial, menyebutkan bahwa sistem jaminan sosial nasional adalah program negara yang 
mempunyai tujuan memberikan kepastian perlindungan dan juga kesejahteraan sosial untuk seluruh rakyat (Kementerian Kesehatan Republik Indonesia, 2011).

Menghitung jumlah kebutuhan setiap perbekalan farmasi, pengelompokan dan penjumlahan masing-masing perbekalan farmasi, melakukan penghitungan jumlah masing-masing perbekalan farmasi yang diperlukan per penyakit, jumlah kebutuhan perbekalan farmasi yang akan datang dihitung dengan mempertimbangkan peningkatan kunjungan dan kemungkinan hilang, rusak dan kadaluarsa, kebutuhan periode yang akan datang dihitung dengan mempertimbangkan lead time dan stok pengaman merupakan langkah-langkah untuk menghitung kebutuhan perbekalan farmasi (Febriawati, 2013).

Menghitung kebutuhan perbekalan farmasi dapat menggunakan metode konsumsi yang didasarkan atas analisis data konsumsi perbekalan farmasi periode sebelumnya melalui penyesuaian dan koreksi (Febriawati, 2013). Penggunaan metode konsumsi dapat menggunakan langkah-langkah perencanaan sebagai berikut yaitu: langkah evaluasi yang terdiri dari evaluasi rasionalitas pola pengobatan periode lalu, evaluasi suplai obat periode lalu, evaluasi data stok, distribusi, dan penggunaan obat periode lalu, pengamatan kerusakan serta kehilangan obat. Setelah itu jumlah kebutuhan obat periode mendatang dilakukan estimasi dengan memperhatikan perubahan populasi cakupan pelayanan, perubahan pola morbiditas, perubahan fasilitas pelayanan. Kemudian lakukan penerapan perhitungan dengan cara menetapkan periode konsumsi, menghitung penggunaan tiap jenis obat periode lalu, melakukan koreksi terhadap kecelakaan dan kehilangan, dan melakukan koreksi terhadap stock out serta menghitung lead time untuk menentukan safety stock (Febriawati, 2013).

Rumus perencanaan perbekalan farmasi berdasarkan metode konsumsi (Febriawati, 2013):

Keterangan :

$\mathrm{CT}=$ Kebutuhan per periode waktu

$\mathrm{CA}=$ Kebutuhan rata-rata waktu (bulan)

$\mathrm{T}=$ Lama kebutuhan (bulan/tahun)

SS = Safety Stock, dimana cara menghitung SS adalah :

$$
S S=\frac{\text { Lead Time }}{\text { Jumlah hari/Bulan }} \times \text { CA }
$$

Penggunaan metode konsumsi memiliki kelebihan dalam perencanaan perbekalan farmasi yaitu data konsumsi akurat (metode paling mudah), jika data konsumsi dicatat dengan baik, pola preskripsi tidak berubah dan kebutuhan relatif konstan serta tidak membutuhkan data epidemiologi maupun standar pengobatan. (Febriawati, 2013).

Kekurangan metode konsumsi dalam perencanaan perbekalan farmasi yaitu, data konsumsi, data obat dan jumlah kontak pasien kemungkinan sulit untuk didapatkan, tidak dapat diandalkan jika terjadi kekurangan stok obat lebih dari tiga bulan, tidak dapat dijadikan dasar dalam mengkaji penggunaan obat dan perbaikan pola preskripsi, 
pada obat yang berlebih atau ada obat yang hilang, pencatatan data morbiditas yang baik tidak diperlukan (Febriawati, 2013).

Penelitian ini bertujuan untuk Mengetahui kesesuaian proses perencanaan ketersediaan obat dengan metode konsumsi serta mengetahui lead time, buffer stock, sisa stok dan pemakaian rata-rata, dan Faktor yang mempengaruhi ketidaksesuaian perencanaan obat tersebut untuk pasien BPJS Kesehatan rawat jalan di Instalasi Farmasi salah satu Rumah Sakit Umum Daerah di Kabupaten Bandung serta kesesuaian proses perencanaan ketersediaan obat dan mengetahui faktor yang mempengaruhi ketidaksesuaian perencanaan obat untuk pasien BPJS Kesehatan rawat jalan di Instalasi Farmasi salah satu Rumah Sakit Umum Daerah di Kabupaten Bandung dengan metode konsumsi.

Proses perencanaan yaitu bagian dari daur kegiatan manajemen yang terutama berhubungan dengan pengambilan keputusan (decision making) untuk masa depan, baik jangka pendek maupun jangka panjang. (Harahap \& Amanah, 2018)

Penelitian ini dalam jangka panjang dapat digunakan sebagai dasar evaluasi dalam pembuatan kebijakan perencanaan obat untuk pasien BPJS Kesehatan Rawat Jalan di Instalasi Farmasi.

\section{Metode Penelitian}

Penelitian ini merupakan penelitian deskriptif dengan pengambilan data secara retrospektif terhadap laporan jumlah pemakaian dan sisa obat BPJS di Instalasi Farmasi salah satu Rumah Sakit Umum Daerah di Kabupaten Bandung. Penelitian yang dilakukan merupakan jenis penelitian observasional non-eksperimental dengan rancangan deskriptif kuantitatif. (Rachmat Hidayat, Firdaus, \& Lesmini, 2018)

Data penelitian yang digunakan yaitu laporan awal stok obat periode bulan Oktober - Desember 2017, laporan sisa stok obat periode bulan Oktober - Desember 2017, laporan pemakaian rata-rata selama tiga bulan, formularium Rumah Sakit 2017, daftar obat e-catalog 2017, permintaan harian dari depo farmasi BPJS, surat pesanan, faktur, berita acara penerimaan obat di Instalasi Farmasi salah satu Rumah Sakit Umum Daerah di Kabupaten Bandung. (Malinggas, Posangi, \& Soleman, 2015).

Populasi pada penelitian ini adalah semua data pemakaian obat untuk pasien BPJS Kesehatan Rawat Jalan di Instalasi Farmasi salah satu Rumah Sakit Umum Daerah di Kabupaten Bandung selama kurun waktu tiga bulan (Oktober - Desember 2017). Adapun Sampel pada penelitian ini adalah populasi yang diambil dari Sistem Informasi Manajemen Rumah Sakit mengenai data pemakaian obat untuk pasien BPJS Kesehatan Rawat Jalan di Instalasi Farmasi salah satu Rumah Sakit Umum Daerah di Kabupaten Bandung selama kurun waktu tiga bulan (Oktober - Desember 2017) yang memenuhi kriteria inklusi.

Sampel pada penelitian ini menggunakan perhitungan dengan rumus Slovin (Notoatmodjo, 2015)

$n=\frac{N}{1+N(e)^{2}}$ 
Keterangan : $\mathrm{n}=$ ukuran sampel

$\mathrm{N}=$ jumlah populasi

$\mathrm{e}=$ tingkat kesalahan

Berdasarkan jumlah populasi obat bulan Oktober - Desember 2017 didapatkan hasil jumlah obat untuk pasien BPJS Kesehatan Rawat Jalan sebanyak 759 item obat. Maka untuk menentukan ukuran sampel adalah :

$n=\frac{N}{1+N(e)^{2}}$

$n=\frac{759}{1+759(0,1)^{2}}$

$n=88,36$

Dari hasil perhitungan menggunakan rumus slovin, maka diperoleh jumlah sampel yang digunakan adalah 88 item obat/bulan.

Langkah-langkah yang digunakan untuk melakukan penelitian adalah mengurutkan pengeluaran obat ke pasien BPJS Kesehatan rawat jalan dari yang paling banyak hingga yang paling sedikit pengeluarannya. Maka akan diperoleh populasi, menentukan sampel yang akan digunakan dari populasi obat, menyiapkan alat dan bahan yang akan digunakan, menentukan kebutuhan rata-rata sampel tiap bulan, menghitung safety stock masing-masing sampel, menentukan sisa stok masing-masing sampel, melakukan pengolahan data untuk mendapatkan kebutuhan obat per periode waktu, menganalisa data dengan membandingkan antara hasil dari kebutuhan obat per periode waktu dengan obat yang tersedia selama periode tersebut untuk informasi dan evaluasi.

\section{Hasil dan Pembahasan}

\section{A. Hasil Penelitian}

Berdasarkan data perhitungan perencanaan obat untuk pasien BPJS Kesehatan rawat jalan dengan metode konsumsi di Instalasi Farmasi salah satu Rumah Sakit Umum Daerah di kabupaten Bandung didapatkan hasil yaitu dari keseluruhan obat yang digunakan, terdapat beberapa obat yang mempunyai nilai pemakaian terbesar, peringkat pemakaian rata-rata perbulan yang paling besar, dan ditampilkan dalam tabel 1,2,3 sebagai berikut:

Tabel 1

Peringkat pemakaian terbesar bulan Oktober 2017

\begin{tabular}{clcc}
\hline No & \multicolumn{1}{c}{ Nama Obat } & Sediaan & Jumlah \\
\hline 1 & Ask.Neurodex Tabl & Tablet & 60.852 \\
2 & Ask.Amlodipin 10 Tab & Tablet & 60.554 \\
3 & Ask.Furosemid Tabl & Tablet & 50.712 \\
4 & Ask.Acarbose 50mg Tab & Tablet & 32.317 \\
5 & Ask.Concor 2,5 & Tablet & 31.895 \\
\hline
\end{tabular}


Tabel 2

Peringkat pemakaian terbesar bulan November 2017

\begin{tabular}{clcr}
\hline No & \multicolumn{1}{c}{ Nama Obat } & Sediaan & Jumlah \\
\hline 1 & Ask.Amlodipin 10 Tab & Tablet & 60.575 \\
2 & Ask.Furosemid Tabl & Tablet & 53.022 \\
3 & Ask.Neurodex Tabl & Tablet & 47.195 \\
4 & Ask.Lansoprazol & Kapsul & 43.055 \\
5 & Ask.Alpentin 100 & Kapsul & 37.754 \\
\hline
\end{tabular}

Tabel 3

Peringkat pemakaian terbesar bulan Desember 2017

\begin{tabular}{clcc}
\hline No & \multicolumn{1}{c}{ Nama Obat } & Sediaan & Jumlah \\
\hline $\mathbf{1}$ & Ask.Lansoprazol & Kapsul & 55.606 \\
$\mathbf{2}$ & Ask.Alpentin 100 & Kapsul & 39.735 \\
$\mathbf{3}$ & Ask.Neurodex Tabl & Tablet & 38.172 \\
$\mathbf{4}$ & Mecobalamin 500mg Caps & Kapsul & 36.195 \\
$\mathbf{5}$ & Ask.Concor 2,5 & Tablet & 29.930 \\
\hline
\end{tabular}

Perhitungan perencanaan dengan metode konsumsi dilakukan per bulan selama tiga bulan yaitu pada bulan Oktober - Desember 2017. Sampel yang digunakan sebanyak 88 item obat dengan ketelitian 10\%. Untuk menghitung kebutuhan per periode waktu, sebelumnya harus dihitung terlebih dahulu safety stock. Setelah diketahui safety stock masing-masing obat, maka dapat dihitung kebutuhan obat per periode waktu kemudian dilakukan analisa data dengan membandingkan antara hasil dari kebutuhan obat dengan obat yang tersedia selama periode tersebut. (Siregar, 2013).

Pada tabel 4 menunjukkan jumlah obat yang sesuai dan tidak sesuai untuk dilakukan pengadaan terhadap penelitian perencanaan yang di lakukan.

Tabel 4

Persentase kesesuaian ketersediaan obat dengan metode konsumsi

\begin{tabular}{ccccc}
\hline Bulan & Jumlah & Sesuai & Tidak sesuai & $\begin{array}{c}\text { Persentase } \\
\%\end{array}$ \\
\hline Oktober 2017 & 88 & 50 & 38 & 56,82 \\
November 2017 & 88 & 48 & 40 & 54,55 \\
Desember 2017 & 88 & 71 & 17 & 80,68 \\
\hline
\end{tabular}




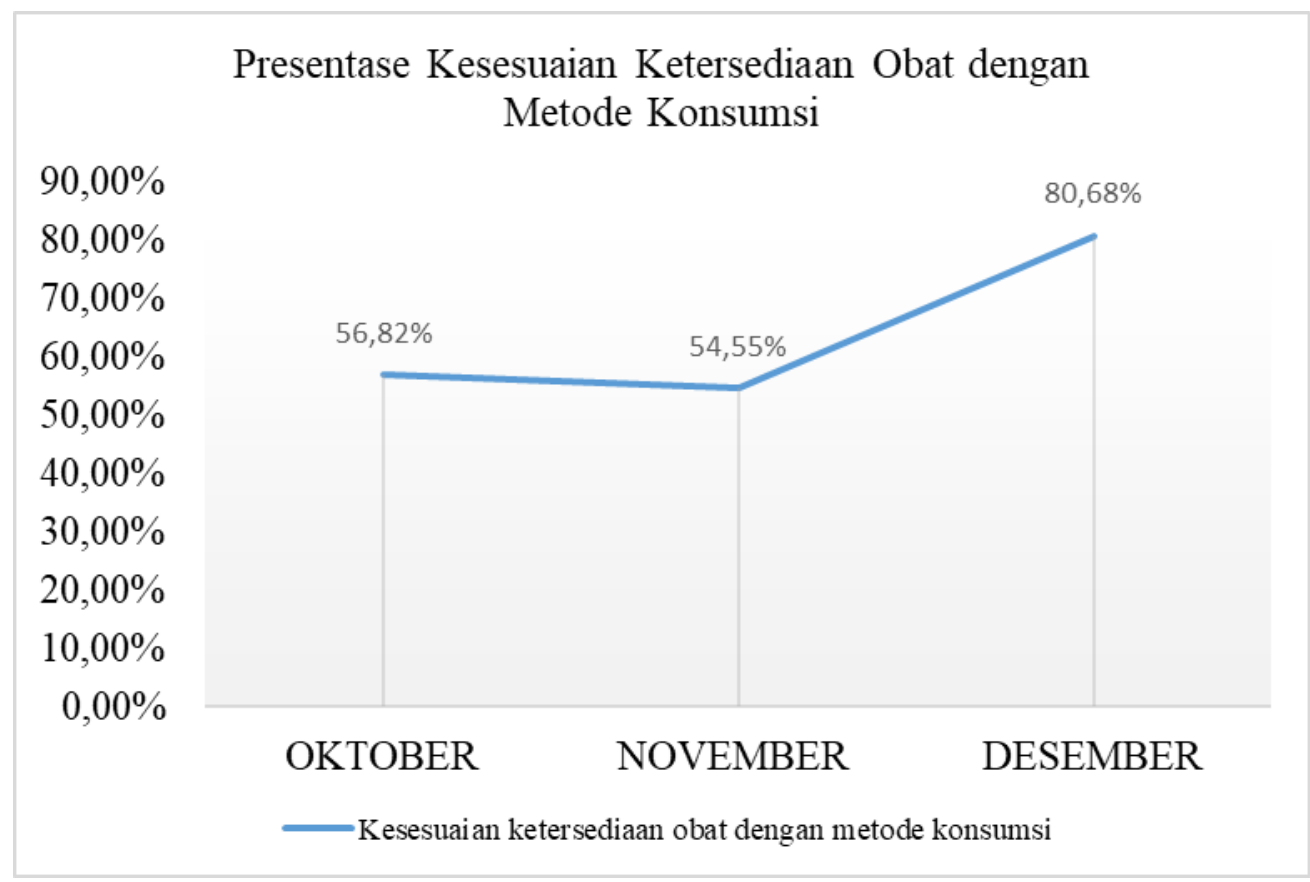

Gambar 1

Persentase kesesuaian ketersediaan obat dengan metode konsumsi

\section{B. Pembahasan}

Menghitung kebutuhan perbekalan farmasi dapat menggunakan metode konsumsi yang didasarkan atas analisis data konsumsi perbekalan farmasi periode sebelumnya melalui penyesuaian dan koreksi (Febriawati, 2013) Kebutuhan periode yang akan datang dihitung dengan mempertimbangkan lead time dan stok pengaman merupakan langkah-langkah untuk menghitung kebutuhan perbekalan farmasi (Febriawati, 2013).

Lead time yang ditentukan berkisar 30 hari untuk obat e-catalog karena menunggu persetujuan dari pusat dan stok obat yang ada di Perusahaan Besar Farmasi Daerah dan 15 hari untuk obat reguler, sedangkan buffer stock yang digunakan adalah 25\%. Daftar obat yang digunakan oleh depo farmasi rawat jalan BPJS Kesehatan di salah satu Rumah Sakit Umum Daerah di Kabupaten Bandung selama periode Oktober - Desember 2017, terdapat 759 obat yang termasuk dalam daftar obat e-catalog dan formularium Rumah Sakit 2017. Berdasarkan hasil penelitian jumlah sampel obat yang diambil yaitu 88 item obat/bulan dengan batas ketelitian 10\%. Dimana sampel tersebut terdiri dari 57 item obat yang masuk daftar e-catalog atau sekitar $64,77 \%$ dan 31 item obat reguler yang masuk daftar formularium Rumah Sakit 2017 atau sekitar 35,23\%. Data yang digunakan untuk analisis perencanaan obat berdasarkan metode konsumsi adalah data periode Oktober - Desember 2017 khusus obat - obatan yang digunakan oleh pasien rawat jalan di depo farmasi BPJS Kesehatan. Perhitungan perencanaan obat berdasarkan metode konsumsi dalam penelitian ini dihitung berdasarkan rumus yang ditentukan oleh faktor-faktor antara lain : pemakaian rata-rata perbulan, lead time, buffer stock, 
dan sisa stok pada bulan tersebut. Dari tabel 1, 2 dan 3 didapatkan hasil peringkat konsumsi obat pada bulan Oktober-Desember 2017. Pada bulan Oktober, obat yang paling banyak digunakan adalah Ask. Neurodex dengan jumlah pemakaian 60.852 tablet. Pada bulan November 2017, obat yang paling banyak digunakan adalah Ask. Amlodipin 10 tab dengan jumlah pemakaian sebesar 60.575 tablet. Dan pada bulan Desember 2017, obat yang paling banyak digunakan adalah ask. Lansoprazol dengan jumlah pemakaian sebesar 55.606 kapsul. Ternyata hasil yang didapat tingkat konsumsi penggunaan obat tersebut berbeda setiap bulannya. Hal ini disebabkan karena peresepan dokter tiap bulannya berbeda. Rencana kebutuhan obat BPJS Kesehatan dihitung dengan cara mengkalikan kebutuhan rata - rata perbulan dengan lama kebutuhan perbulan ditambah safety stock dikurangi sisa stok. Safety stock terbanyak pada bulan Oktober 2017 adalah Ask. Amlodipin 10 Tab dengan jumlah 69.870, pada bulan November 2017 adalah Ask. Amlodipin 10 Tab dengan jumlah 69.894 dan pada bulan Desember 2017 adalah Ask. Lansoprazol dengan jumlah 72.530 .

Hasil dari perhitungan pemakaian periode bulan Oktober-Desember 2017 didapatkan bahwa dari 88 sampel yang diambil tiap bulan, pada bulan Oktober 2017 yang sesuai untuk diadakan pengadaan adalah 50 item dan 38 item tidak sesuai untuk diadakan pengadaan. Pada bulan November 2017 yang sesuai untuk diadakan pengadaan adalah 48 item dan yang tidak sesuai untuk diadakan pengadan adalah 40 item. Pada bulan Desember 2017, yang sesuai untuk diadakan pengadaan adalah 71 item dan yang tidak sesuai untuk diadakan pengadaan adalah 17 item. Hal ini dapat dilihat dari jumlah kebutuhan barang per periode waktu lebih besar dibandingkan dengan jumlah barang yang datang ditambah stok barang di awal bulan. Ini merupakan salah satu faktor yang menyebabkan pelayanan resep untuk pasien BPJS Kesehatan rawat jalan di Instalasi Farmasi salah satu Rumah Sakit Umum Daerah di Kabupaten Bandung terhambat. Perbandingan yang didapatkan dari hasil penelitian pada perencanaan RSUD Tidar Kota Magelang bahwa $61 \%$ sesuai dengan perencanaan dan $39 \%$ tidak sesuai dengan perencanaan penelitian. Penetapan kebutuhan obat menggunakan analisa konsumsi dengan mempertimbangkan beberapa aspek dalam perencanaan obat di rumah sakit yaitu pemakaian periode sebelumnya, anggaran, standarisasi obat atau formularium, kapasitas gudang dan stok akhir, lead time dan stok pengaman, jumlah kunjungan dan pola penyakit serta standar terapi (Murtafi et al., 2014).

Pada gambar 1 menunjukkan, pada bulan Desember 2017 mengalami kesesuaian pengadaan dengan persentasi yang cukup tinggi, yaitu $80,68 \%$. Ini terjadi karena, pengadaan obat untuk bulan Desember 2017 dilakukan 2 kali lipat. Hal tersebut dilakukan untuk menghindari kekosongan obat di bulan Januari 2018. Karena setiap pergantian tahun, maka kontrak pengadaan pun mengalami perubahan dan memakan waktu yang lama, sehingga akan menghambat pada proses pengadaan yang menyebabkan terkendalanya pada pelayanan resep. Pada bulan Oktober dan November 2017 mengalami kesesuaian pengadaan terhadap 
perencanan dengan persentase $56,82 \%$ dan $54,55 \%$ ini menunjukkan adanya faktor yang mempengaruhi ketidaksesuaian perencanaan dan pengadaan obat BPJS Kesehatan dengan terjadi diantaranya disebabkan:

a) Pending (ditunda pengiriman oleh distributor) merupakan alasan terbanyak untuk kekosongan gudang. Hal ini disebabkan rumah sakit belum menyelesaikan kewajiban pembayaran kepada pihak distributor, sehingga produk tidak dapat dikirim. Keterlambatan pembayaran ini salah satu sebabnya adalah pembayaran dari pihak BPJS yang juga terlambat, yang juga disebabkan berkas klaim dari pihak rumah sakit juga tidak tepat waktu.

b) Kosong distributor. Ini menjadi masalah tersendiri bila terjadi kekosongan dipihak distributor, karena distributor tidak bertanggung jawab untuk mengadakan barang yang kosong tersebut, tetapi harus ditanggulangi sendiri oleh bagian pengadaan untuk mencari di distributor lain, ataupun diganti dengan generik yang sama. Perlu penekanan dalam perjanjian kerjasama, bahwa rekanan atau distributor harus bertanggung jawab dalam pengadaan produk yang itemnya sudah tercantum dalam perjanjian. (Romauli, 2016)

c) Belum terpesankan. Hal ini memerlukan perencanaan waktu yang tepat untuk menyampaikan pesanan kepada distributor agar stok yang ada masih dapat memenuhi kebutuhan pasien ketika menunggu masa pengiriman, dengan memperhitungkan kondisi pending rumah sakit, juga lead time nya (waktu tunggu) pengiriman.

d) Produk sudah tidak masuk daftar $e$-catalog. Untuk yang sudah tidak masuk $e$ catalog, memang seharusnya tidak dipesankan kembali karena untuk pelayanan obat BPJS pembelian obat e-catalog dapat meminimalkan biaya dengan harga yang cukup ekonomis, dibandingkan dengan harga reguler. Perlu adanya stok pengaman (safety stock) untuk mengantisipasi kebutuhan produk agar pelayanan dapat tetap berjalan lancar (Febriawati, 2013).

Hasil penelitian ini memiliki kebaruan sebagai dasar penyusunan kebijakan perencanaan obat dan dalam jangka panjang dapat digunakan sebagai dasar evaluasi dalam pembuatan kebijakan perencanaan obat serta menjamin ketersediaan obat untuk meningkatkan kepuasan pelayanan bagi pasien BPJS Kesehatan Rawat Jalan di Instalasi Farmasi.

\section{Kesimpulan}

Hasil penelitian di Instalasi Farmasi salah satu Rumah Sakit Umum Daerah di Kabupaten Bandung mengenai perencanaan obat untuk pasien BPJS Kesehatan rawat jalan dengan metode konsumsi, memberikan hasil kesesuaian perencanaan dengan menggunakan metode konsumsi, didapatkan hasil kesesuaian pengadaan obat pada bulan Oktober, November dan Desember 2017 berturut-turut adalah 56,82\%, 54,55\% dan $80,68 \%$. Faktor yang mempengaruhi ketidaksesuaian perencanaan obat diantaranya: pending, kosong distributor, belum terpesankan dan produk sudah tidak masuk daftar $e$ catalog. Perlunya pelatihan bagi karyawan instalasi farmasi terutama yang bertugas 
Kamelia Agustini, Akhmad Priyadi dan Nurul Fauziah

untuk mengelola perbekalan farmasi, pengawasan perlu dilakukan dengan rutin, kelancaran pembayaran, perluasan ruangan terutama di gudang farmasi dan depo rawat jalan, serta perencanaan yang memprioritaskan obat yang paling banyak digunakan untuk diadakan secara penuh, dan dapat menggunakan metode konsumsi dalam melakukan perencanaan. 


\section{BIBLIOGRAFI}

Febreani, Stella Herliantine, \& Chalidyanto, Djazuly. (2016). Pengelolaan Sediaan Obat Pada Logistik Farmasi Rumah Sakit Umum Tipe B di Jawa Timur. Jurnal Administrasi Kesehatan Indonesia, 4(2), 136. https://doi.org/10.20473/jaki.v4i2.20 16.136-145

Febriawati, Henni. (2013). Manajemen Logistik Farmasi Rumah Sakit. Yogyakarta: Gosyen.

Harahap, Dedy Ansari, \& Amanah, Dita. (2018). Pengantar Manajemen. Bandung: Alfabeta. https://doi.org/10.31227/osf.io/3ub4t

Kementerian Kesehatan Republik Indonesia. (2011). Undang-undang Republik Indonesia No.24 Tahun 2011 Tentang Badan Penyelenggara Jaminan Sosial.

Kementerian Kesehatan Republik Indonesia. (2014). Peraturan Menteri Kesehatan Republik Indonesia Nomor 56 tahun 2014 tentang Klasifikasi dan Perizinan Rumah Sakit.

Kementerian Kesehatan Republik Indonesia. (2016). Peraturan Menteri Kesehatan Republik Indonesia Nomor 72 tahun 2016 tentang Standar Pelayanan Kefarmasian di Rumah Sakit.

Malinggas, Novianne E. R., Posangi, J., \& Soleman, T. (2015). Analysis of Logistics Management Drugs In Pharmacy Installation District General Hospital Dr . Sam Ratulangi Tondano kesehatan bagi masyarakat dengan merupakan salah satu kegiatan di rumah satu unit di rumah sakit yang bertugas dan merupakan salah satu se. Analisis Manajemen Logistik, 5, 448-460.

Mendrofa, Devina Eirene, \& Suryawati, Chriswardani. (2016). Analisis Pengelolaan Obat Pasien BPJS Di Instalasi Farmasi Rumah Sakit Panti Wilasa Citarum Semarang. Jurnal Manajemen Kesehatan Indonesia, 4(3), 214-221. https://doi.org/10.14710/jmki.4.3.2016.214-221

Murtafi, Lailatul, Yuliastuti, Fitriana, \& Hidayat, Imron Wahyu. (2014). Di Instalasi Farmasi Rsud Tidar Kota Magelang Periode Juni-Agustus 2014 Analysis of Drug Planning Based on Consumption Method in Pharmacy Unit Tidar Magelang Hospital Period June-August of 2014. I(2), 22-29.

Notoatmodjo, Soekidjo. (2015). Metodologi Penelitian Kesehatan. Jakarta: Rineka Cipta.

Rachmat Hidayat, Raden Didiet, Firdaus, Mohammad Iqbal, \& Lesmini, Lis. (2018). Pengelolaan Gudang Logistik Kemanusiaan Bnpb. Jurnal Manajemen Industri Dan Logistik, 1(2), 75-90. https://doi.org/10.30988/jmil.v1i2.8 
Kamelia Agustini, Akhmad Priyadi dan Nurul Fauziah

Ristono, A. (2018). Manajemen Persedian. Yogyakarta: Graha Ilmu.

Romauli. (2016). Perencanaan Pengadaan Obat di Rumah Sakit Umum Daerah (RSUD) Kabupaten Kepulauan Meranti. JOM Fisip, 3 (1).

Rumbay, Inggrid N., et all. (2015). Analisis Perencanaan Obat di Dinas Kesehatan Kabupaten Minahasa Tenggara. Jurnal Ilmu Kesehatan Masyarakat Unsrat, $2 b$ (5).

Siregar, Charles J. .. (2013). Farmasi Rumah Sakit Teori dan Terapan. Jakarta: Penerbit Buku Kedokteran EGC. 